\title{
有限要素解に基づく斜面浅部の地下水位上昇量の簡易予測式の提案 A simple prediction model for shallow groundwater level rise in natural slopes based on finite element solutions
}

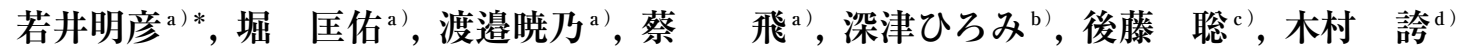 \\ Akihiko WAKAI, Kyosuke HORI, Akino WATANABE, Fei CAI, Hiromi FUKAZU, Satoshi GOTO and Takashi KIMURA
}

\begin{abstract}
Nowadays, it has become easy for us to use the spatially distributed rainfall data observed by weather radars. Such highresolution data allows us to predict groundwater rising in each individual slope due to torrential rain in a short period, using reliable numerical techniques such as finite element analysis of saturated-unsaturated seepage. However, usually a high-spec calculator and a long period of calculation time are required to carry out such rigorous simulations, and it means that such a method cannot satisfy the engineers who are concerned with real-time simulation used for early warning processes. In this study, a simple method for prediction of shallow groundwater rising in natural slopes in time history will be developed based on the parametric studies with the finite element analysis under the assumption of semi-infinite homogeneous slope. By referring the hydraulic head predicted by the proposed method and the observed shear strength of soil material in the slope, it becomes possible to facilitate a real-time evaluation for the degradation of the total factor of safety for slope failure from moment to moment.
\end{abstract}

Key words : groundwater level, semi-infinite slope, finite element method, seepage analysis

\section{和文要旨}

近年，気象レーダー等から推定される雨量強度の空間分布のデジタル情報を使うことが容易となり，例えば，FEMに基づく飽和 一不飽和浸透流解析のような高精度解析技術を用いることで, 短時間の集中豪雨による斜面内の地下水位上昇の様子を再現するこ とが可能となっている。しかしながら，こうした数值解析には，高性能計算機と長時間演算が必要となることが多く，解析雨量に 基づくリアルタイムの早期警戒判断などにその解析結果を利用したい技術者にとっては制約も大きい。そこで本研究では，斜面内 の浅層地下水の水位上昇の時刻歴を予測するための簡易な計算方法を，半無限斜面仮定の下で実施した一連の有限要素解析のパラ メトリック・スタディの結果に基づいて開発した。将来，本手法で予測された地下水位と斜面材料のせん断強度に基づいて，時々 刻々と変化する表層崩壊に対する安全率の低下をリアルタイムで評価することが可能となる。

キーワード：地下水位, 半無限斜面, 有限要素法, 浸透流解析

\section{1.はじめに}

斜面崩壞や土砂災害の危険度評価において，物理則モ デルをもとに水文解析や斜面安定解析等を行う場合には, 入力值として正確な雨量データが観測されていることが 重要である。わが国には高性能のXバンドMPレーダー が全国に配備され, 高密度の地上観測網による雨量計測 が行われて㧍り，こうした気象レーダーのデータを用い た土砂災害の危険度評価手法，特に，短時間演算を前提 とした手法の提案が増えている(例えば，三隅ほか, 2004, 沖村ほか, 2011, 木下ほか, 2013,など)。分布型の水文解 析から求めた地下水位条件を斜面安定解析手法に接続す ることでリアルタイム評価が可能となるが，このような 気象レーダーを活用した土砂災害の危険度評価は世界的 な潮流（例えば, Shi et al., 2018）とも言え, 同様の試 みは今後一層増加すると考元られる。水文解析の演算時 間を節約するため,こうした研究においては, 簡易な貯留

* 連絡著者/corresponding author

a) 群馬大学

Gunma University

于 $376-8515$ 群馬県桐生市天神町1-5-1

$1-5-1$, Tenjin, Kiryu, Gumma $376-8515$

b) JR東日本コンサルタンツ株式会社

JR East Consultants Company

UR East

University of Yamanashi

d) 防災科学技術研究所

National Research Institute for Earth Science and Disaster Resilience
関数法や，斜面全体の水文特性をかなり単純化した浸透 流計算が採用されることが多い。そこで著者らは，これ らの先行する研究等に資する試みとして, 雨水が地表面 から浸透して地下水位を上昇させる過程をさらに精度よ く再現するためのFEMに基づく簡易予測式を提案する。 計算機技術の発展に従って, 斜面内の地下水移動の再 現解析においても，不飽和領域の水分保持特性などを考 慮した飽和一不飽和浸透流解析のFEM計算アルゴリズ ムが開発され，斜面内の浸透現象に対する各種の解析的 研究がなされてきた（Ng \& Shi, 1998, Cho \& Lee, 2001, Kim et al., 2004, Zhang et al., 2004)。こうした解析手法 の普及は, 実斜面へのFEMの工学的利用 ( $\mathrm{Ng}$ et al, 2001, Cascini et al., 2010）や，現地計測データを援用した機 構解析 (Rahardjo et al., 2005, 酒匂ほか, 2007) など, 応用的な研究をさらに加速させた。これまでに著者の一 部 (Cai \& Ugai, 2004) も同様のFEM計算コード （VGFLOW）を開発し，これを斜面の豪雨時の安定性評 価や対策工評価等に応用している（若井ほか, 2000, 信岡 ほか, 2009)。

以上に対して, 本FEM研究の目的は, 個々の斜面地 点の豪雨継続中の地下水位の深さ（ただし, 浅層の地下 水位に限る）を時刻歴で予測する簡易計算法を提案する 
ことである。不飽和浸透理論に基づいて地中の一次元鉛 直浸透現象を予測する試みは以前からある（例えば，平 松ほか,1990）が，本研究はこうした手法をさらに高度 化する検討のひとつと位置づけられ，半無限斜面仮定の 下で実施したFEMによる飽和一不飽和浸透流解析のパ ラメトリック・スタデイに基づいて，FEMと近い精度 を有する簡易な予測式を構築する。これによって，高性 能計算機による演算が不要となり, 斜面の表層崩壊に対 する安全率の低下をリアルタイム評価することが飛躍的 に容易となる。例えば，本稿の関連研究として，火山灰 地域でのテフラ層厚の分布を考慮した斜面崩壊危険地の 新たな抽出手法が木村ほか（2019）により提案されてい るが，こうした安全率計算に基づく危険度評価手法の入 力条件として，本稿で提案する手法にもとづいた非定常 降雨による地下水位の応答時刻歴のデー夕を利用可能で ある。

いずれにせよ，本研究は集中豪雨時の表層崩壊に対す る危険度評価への応用に主眼を置いており, 哚層の地下 水位の変化や，雨がやんだ後の排水ならびに地下水位の 低下を予測することは当面の研究対象としていない。た だし，これらも実務上の重要課題であるため, 将来は計 算手法の拡張のための発展的研究が望まれる。

\section{2. 解析モデル}

\section{1 飽和一不飽和浸透流解析}

本研究で用いる雨水浸透現象のシミュレーション手法 の詳細はCai \& Ugai（2004）に述べられているので, こ こでは支配方程式の概要のみを述べる。地中の間隙水圧 の上昇は，降雨によって涵養された水分が地表に近い不 飽和土層内の含水率を徐々に高めるとともに，その一部 がゆっくりと深部へ移動して, 飽和領域（带水層）が次 第に拡大していく過程として数理的に表現される。

不飽和土の透水係数を，体積含水率 $\theta$ （すなわち，土 の間隙率 $n$ と飽和度 $S_{r}$ の積）の関数 $K(\theta)$ であると仮定す

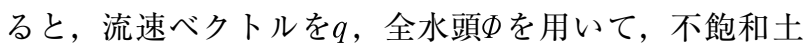
におけるダルシーの法則は下式で表される。

$$
q=-K(\theta) \nabla \Phi
$$

全水頭Фは，圧力水頭（不飽和状態ではサクション） $\varphi$ と位置水頭 $z$ の和で表される。

$$
\Phi=\varphi+z
$$

一方, 水の密度を $\rho_{w}$ とすると, 土の間隙を通る水の質 量保存則（連続の方程式）は次式で記述される。

$$
\nabla^{T}\left(\rho_{w} q\right)=-\frac{\partial}{\partial t}\left(\rho_{w} \theta\right)
$$

ここで, 圧力水頭の変化による水の圧縮性を無視し, 不飽和領域に扔いては圧力水頭の変化による間隙率の変 化が生じないものと仮定すると，(2.1）から（2.3）式
より，飽和一不飽和浸透流の支配方程式が得られる。

$$
\begin{aligned}
& \nabla^{T}[K(\theta) \nabla(\varphi+z)]=\left[c(\varphi)+\alpha S_{s}\right] \frac{\partial \varphi}{\partial t} \cdots \\
& \text { ここに, } \alpha=\left\{\begin{array}{ll}
1, & S_{r}=100 \% \\
0, & S_{r}<100 \%
\end{array}\right. \text { である。 }
\end{aligned}
$$

また, $S_{s}=\frac{d n}{d \varphi}$ は比貯留係数,

$c(\varphi)=\frac{d \theta}{d \varphi}$ は比水分容量である。

比貯留係数は圧力水頭が上昇した際に単位体積当たり の土塊に吸入される水量を表す係数であり，この係数が 大きいほど水位変動に伴う地下水の吸入量が大きい。一 方，比水分容量は，不飽和土において圧力水頭の増分に 対する体積含水率の変化の割合を表す。浸透が進行して 飽和すると比水分容量はゼロとなり，上式は飽和土の支 配方程式になる。

以上を有限要素に離散化し，初期条件，境界条件に基 づいて物理量の空間分布の時刻歴を求解するのが，いわ ゆる有限要素法に基づく飽和 一不飽和浸透流解析である。 本検討では，このようなモデルを実装した有限要素解析 コード (VGFLOW) (Cai \& Ugai, 2004) に基づいて, 斜 面内の雨水浸透機構を解析する。

土の物性として，土の体積含水率とサクションとの関 係を表す曲線を一般に水分特性曲線と呼ぶが，本検討に おいては，van Genuchtenモデル（1980）(以降「VGモ デル」と略）を用いて水分特性曲線と不飽和透水係数を 表現する。VGモデルを記述するために用いられる数式 群を以下に列挙する。

$$
\begin{aligned}
& S_{e}=\frac{\theta-\theta_{r}}{\theta_{s}-\theta_{r}}=\left(1+|\alpha \varphi|^{n_{v}}\right)^{-} \\
& c(\theta)=\alpha\left(n_{v}-1\right)\left(\theta_{s}-\theta_{r}\right) S_{e}^{\frac{1}{m}}\left(1-S_{e}^{\frac{1}{m}}\right)^{m} . \\
& K(\theta)=K_{s} K_{r}=K_{s} S_{e} e^{1 / 2}\left[1-\left(1-S_{e}^{\frac{1}{m}}\right)^{m}\right]^{2}
\end{aligned}
$$

ここで， $S_{e}$ は相対飽和度， $\theta_{r}$ と $\theta_{s}$ は残留および飽和体 積含水率， $K_{s}$ と $K_{r}$ は飽和㧍よび相対透水係数である。 $\theta_{r}$ は浸透移動しない水分に相当する体積含水率の値，すな わち重力に抵抗して土が保持している水分量である（粗 粒土では $\theta_{r}$ はほぼゼ口)。一方， $\theta_{s}$ は通常は土の間隙率 と等しい值である。 $\alpha, n_{0}$ 䇽よび $m$ は経験的なパラメー

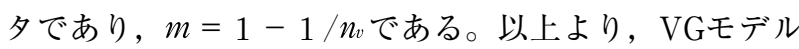

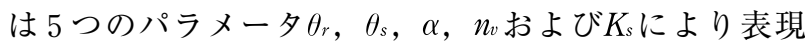
できる。

\section{2 典型的なVGモデルのパラメータ例（飽和透水係 数 $K_{s}=1.0 \times 10^{-3} \mathrm{~m} / \mathrm{s}$ あるいは1. $0 \times 10^{-4} \mathrm{~m} / \mathrm{s}$ 程度 の透水性を有する材料の場合)}

広域的視点の防災シミュレーションへの応用を想定し た場合，個別の斜面の浸透特性について，あらかじめ各 
表一 1 各材料の浸透特性パラメータ.

Table 1 Hydraulic parameters for each material.

\begin{tabular}{c|c|c|c|c|c|c}
\hline & 飽和透水係数 & 残留体積含水率 & 飽和体積含水率 & 比貯留係数 & \multicolumn{2}{|c}{ VG モデルのパラメータ } \\
\cline { 5 - 6 } & $K_{S}[\mathrm{~m} / \mathrm{s}]$ & $\theta_{r}[-]$ & $\theta_{s}[-]$ & $S_{S}[1 / \mathrm{m}]$ & $\alpha[1 / \mathrm{m}]$ & $n_{v}$ \\
\hline 中砂 & $1.0 \times 10^{-4}$ & 0 & 0.30 & $2.0 \times 10^{-4}$ & 5.22 & 5.678 \\
\hline 粗砂 & $1.0 \times 10^{-3}$ & 0 & 0.30 & $1.3 \times 10^{-4}$ & & \\
\hline
\end{tabular}

斜面の詳細な地層構造や水分保持特性などが把握できて いることは少なく，大まかな地質等に基づいて透水係数 のオーダーが推定できる，といった程度の粗い条件しか 与えられていないことが考えられる。そこで，以降のパ ラメトリック・スタディにおいては，飽和透水係数 $K_{s}$ が $1.0 \times 10^{-3} \mathrm{~m} / \mathrm{s}$ （粗砂）または $1.0 \times 10^{-4} \mathrm{~m} / \mathrm{s}$ （中砂）の いずれかの典型的な浸透特性を有する材料から成る斜面 を仮定した。本節では，これらそれぞれの材料に対応す る解析パラメータの具体的数值を紹介する。

水分特性曲線と不飽和透水係数については, 透水試験 等を行った際に直接計測した值を用いることが理想であ るが，試験条件の制約などから，やむを得ず経験的な值 を採用する場合がある。例えば, 飽和透水係数 $K_{s} に つ$ いては, 各試料の粒度試験で得られた $\mathrm{D}_{20}$ の值をもとに, Creagerの経験式（土質工学会, 1967）等から推定する ことが考えられる。飽和体積含水率 $\theta_{s}$ は，地盤の間隙率 と等しいため, 土質試験より得られた間隙比 $e$ から間隙 率 $n$ を算出して採用できる。今回の両材料のように飽和 透水係数が異なると $\theta_{s}$ の值も異なることが考えられるが, 今回は細部になるべく手を加えない簡易な仮定として， いずれの材料においても同じ值（0.30）を用いた。 $\theta_{r}$, $\theta_{s}, \alpha, n_{v}$ については, 例えば, 西垣・竹下 (1993), Carsel \& Parrish(1988)の報告を, 比貯留係数はDomenico \& Schwartz(1990)による值をそれぞれ参照することが考 えられる。

以上に基づいて，飽和透水係数 $K_{s}$ が $1.0 \times 10^{-4} \mathrm{~m} / \mathrm{s}$ (中 砂）もしくは $1.0 \times 10^{-3} \mathrm{~m} / \mathrm{s}$ (粗砂) の材料を想定した 典型的なパラメータ・セットを表 -1 に，水分特性曲線 を図- 1 に，それぞれ例示する。簡単化のため，今回は 両材料の水分特性曲線は同一であると仮定した。

なお，これらよりさらに透水係数が小さい材料を仮定 した場合 $\left(K_{s}=1.0 \times 10^{-5} \mathrm{~m} / \mathrm{s}\right.$; 細砂に対応 $)$ の同様の 半無限斜面の解析的検討（若井ほか, 2017）によると, こうした材料では，以降で述べるような浸透現象（一定 時間の降雨が経過した後に地下水位が上昇を開始する) とは大きく傾向の異なった現象一すなわち，飽和帯が表 層から次第に下降していき, それが初期地下水位に達し て間もなく全層が飽和する一を呈することがわかってい る。こうした材料のモデル化は本研究で提案する計算式 とは大きく異なるため，別の機会に譲ることとしたい。

\section{3 初期条件の与え方}

当初から表層付近が飽和に近い場合と，逆に乾燥して いる場合とでは，降雨による地下水位上昇の感度は大き

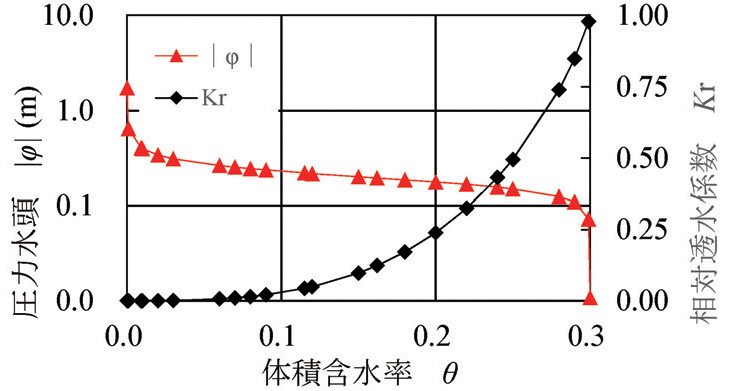

図ー1 VGモデル（表一1）による水分特性曲線および相 対透水係数一体積含水率関係.

Fig. 1 Soil water characteristic curves for each model shown in Table1.

く異なる。以降のパラメトリック・スタディにおいても この点に着目して, 降雨応答解析の前段階の予備計算で 与える飽和度を操作することによって，本番の降雨が開 始する時点での地層内の初期飽和度の大小を変化させた 種々のケースの計算を実現する。ここで, 飽和度 $S_{r}$ は体 積含水率 $\theta$ と間隙率 $n$ を用いて以下の式で表される。

$$
S_{\mathrm{r}}=\frac{\theta}{n} \times 100
$$

一般に間隙率 $n$ と飽和体積含水率 $\theta_{s}$ は等しいと定義で きるため, 飽和度を仮定すると体積含水率が算出される。 すなわち，水分特性曲線を参照することで自動的にサク ションの值（圧力水頭）が決定される。

なお，計算の安定化のためには，本番の降雨を地表面 に入力する前に, 水圧分布の安定化を図っておくことが 望ましい。そこで計算開始前の暫定の飽和度を仮定し， 対応する圧力水頭をいったん全節点に与えた上で，降雨 強度 $0 \mathrm{~mm} / \mathrm{h}$ （ダミー降雨）を入力した平衡計算を行う。 計算の継続につれて，水圧の值の変化が小さくなり，や がて安定して滑らかな分布となれば，降雨入力の準備は 完了である。計算開始前に仮定する飽和度の大小に応じ て, 平衡計算後に得られる地下水位の高さは異なるため, 次章以降ではその飽和度を $40 \%$ もくは $60 \%$ とえた各 ケースのFEM計算を実施する。なお，後述のように， 結果として平衡計算後に得られる不飽和層内の平均飽和 度の大きさはこれらの值とはいずれも異なることに注意 されたい。

\section{3. 水平地盤の一次元鉛直浸透のシミュレーション}

\section{1 基本ケース}

以降の一連のパラメトリック・スタディに先立ち, 基 
本ケースとして，均質な土質からなる水平地盤内の一次 元鉛直浸透のシミュレーションを行い, 地下水位の変動 傾向を表現できる簡易な計算モデルの構築を試みる。

地表面から梁さ $2 \mathrm{~m}$ までの地層の材料特性として表一 1 における「中砂」のパラメー夕を与え，その下面は基 盤と仮定して不透水層とした。前章で述べたように，初 期条件として地層内の含水状況を仮定しなくてはならな いが，本節で紹介するケースにおいては，ダミー降雨後 （すなわち，降雨応答計算の開始直前）の不飽和層内の 平均飽和度が約 $20.0 \%$ になるような水圧条件を与えた。 水圧ゼロの深さを地下水位と見なすならば，本ケースに おける初期の地下水位は地表面から約 $1.11 \mathrm{~m}$ の深さに位 置する。次節においては，本ケースで降雨強度を $10 \mathrm{~mm}$ /h（一定）とした時のFEMによる解析結果を紹介する。

\section{2 降雨強度 $10 \mathrm{~mm} / \mathrm{h}$ (一定) の解析結果}

降雨 $($ 降雨強度 $10 \mathrm{~mm} / \mathrm{h}$ ) 開始後, 時間経過につれて 変化する地層内の圧力水頭（間隙水圧に比例）の分布を 図-2に,このうちの一部の時刻における地層内の飽和 度の分布を図-3にそれぞれ示す。図- 2 より, 初期に 約 $1.11 \mathrm{~m}$ の深さにあった地下水位（水圧ゼロの深さ）が 降雨の継続とともに次第に上昇する。また，図ー 3 によ
ると，地表面から浸透した雨水が地下水位の深さにまで 徐々に浸透していく過程で地下水位以浅の地層内での飽 和度はほぼ一様に上昇し，それがある一定の值に達した 後，地下水位の上昇が始まっていることがわかる。図一 4 に地下水位の時間的変化と, 不飽和層内（地下水位以 浅）の平均飽和度の時間的変化を示す。降雨開始からお よそ3.5時間後に地下水位の上昇が始まり，およそ 12.7 時間後に地下水位は地表面付近まで達している。これを 簡易なモデルで表現する一つの方法として，例えば，水 位が上昇せずに不飽和層内の飽和度がほぼ一定速度で上 昇する時間帯と, 水位がほぼ一定の速度を維持して上昇 する時間带の二つに分離するモデル化が考えられる。な お，図-1で仮定した水分特性曲線と大きく異なる特性 の砂，例えば，細砂により近い水分特性曲線を有する砂 を対象とする場合には，上記のモデル化が必ずしも適当 でない場合も考えられることに注意されたい。

\section{3 簡易予測式 (補正前) の提案}

前節の考察に基づいて, 本研究の主眼である地下水位 の上昇の時刻歴を表現する簡易モデルを提案する。なお， 後の章で述べるように, パラメトリック・スタディに基 づいた検討に基づいて，本節でこれから提案するモデル

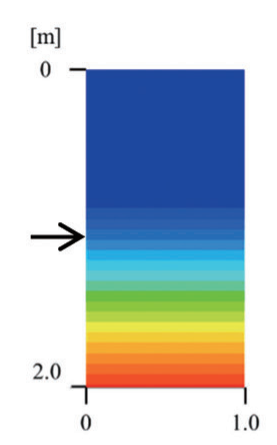

$\rightarrow$ 地下水位 (圧力水頭 $=$ ゼロ)

0 時間後（初期）

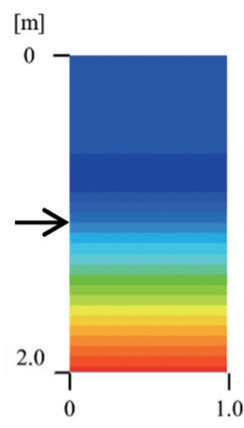

3 時間後

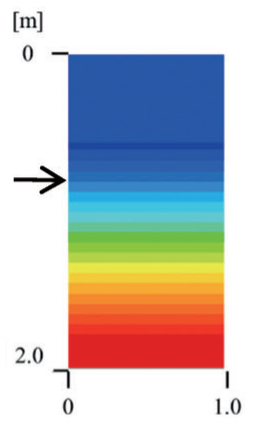

6 時間後
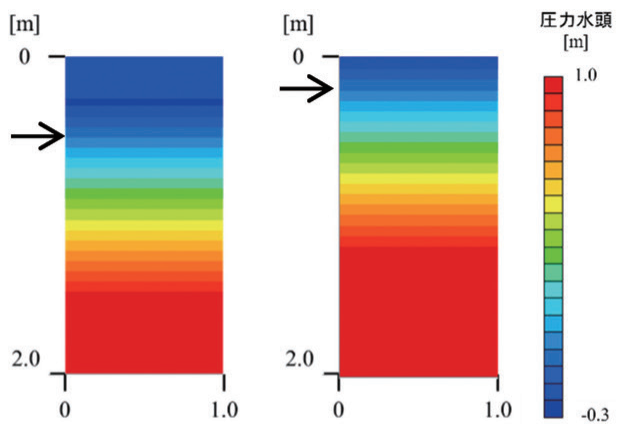

12 時間後

図－２各時刻の圧力水頭の分布（基本ケース）.

Fig. 2 Pressure head distributions at each time step (Standard Case).
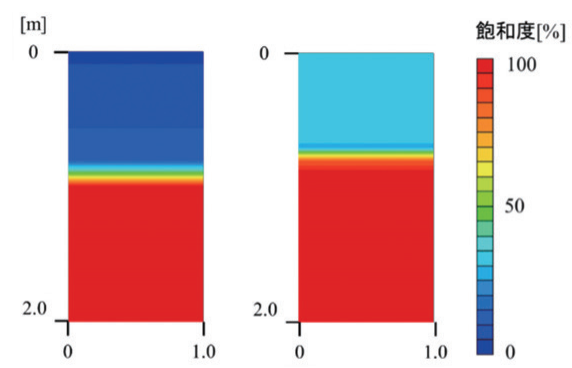

0 時間後（初期）

5 時間後

図一 3 各時刻の飽和度の分布（基本ケース）.

Fig. 3 Distribution of degree of saturation at each time step (Standard case).

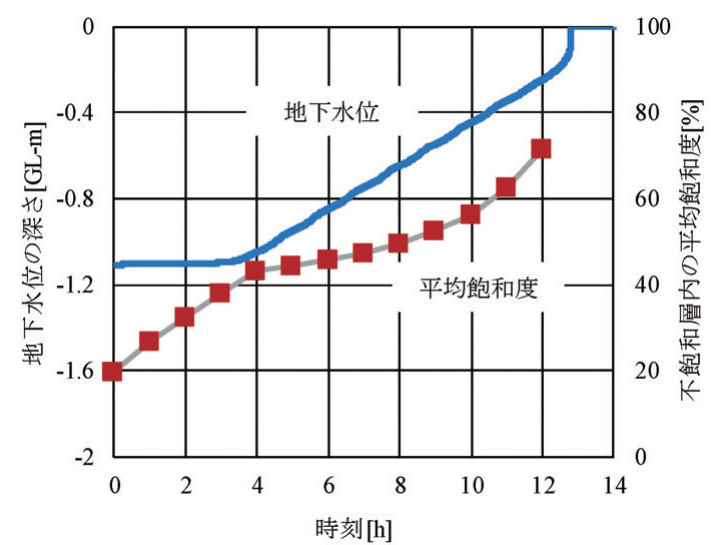

図一 4 水位と平均飽和度の時刻歴（基本ケース）.

Fig. 4 Time histories of ground water level and degree of saturation (Standard case). 
は後ほど若干補正されることに注意されたい（このため， 本節では「補正前」と限定呼称している)。

土中水は地下水位以深の飽和領域と以浅の不飽和領域 とに分けられるが，降雨により地表面から浸透した水は， 不飽和領域を通過してやがて地下水位の位置まで下方移 動する。しかし, 不飽和領域の飽和度が低いと, 浸透水 は下方移動の途中で毛管作用等によって地層内に引き留 められることになる。降雨初期におけるこのような作用 を考虑するには，不飽和領域内に蓄えられる水分の総容 量のようなものを考え，それを超過する量の累積降雨量 があった時にのみ地下水位が上昇を開始すると考えれば よい。すなわち, 不飽和層中の体積含水率 (平均值) が ある一定値 $\theta_{c p}$ 超えた時, はじめて浸透水は不飽和領 域に引き止められずに，持続的に下方の飽和領域へと供 給されると考える。例えば，地下水位が上昇し始める瞬 間の不飽和層全体の臨界平均飽和度を $S_{r}^{*}[\%]$, 間隙率 （飽和体積含水率 $\theta_{s}$ に等しい）を $n$ とすると,

$$
\theta_{c p}=n \frac{S_{r}^{*}}{100}
$$

以降に述べる種々の条件下でのパラメトリック・ス夕 ディの結果から， $\theta_{c p}$ の值をその条件に応じてあらかじ め決めておくことができれば，上式より，地下水位が上 昇し始める瞬間の不飽和層全体の臨界平均飽和度 $S_{r}^{*}$ を 推定することが可能となる。

一定の降雨強度 $I$ (単位時間当たりの累積水柱高さ) の降雨を想定する場合，雨水のすべてが地中にそのまま 浸透していると仮定すれば, 降雨開始時点の不飽和層(鉛 直厚さ $: h[\mathrm{~m}])$ 全体の初期平均飽和度を $S_{r 0}$ として, 地 下水位が上昇し始めるまでの経過時間 $t_{1}[\mathrm{~h}]$ は,

$$
t_{1}=\frac{n\left(S_{r}^{*}-S_{r 0}\right) h}{100 I}=\frac{h}{I}\left(\theta_{c p}-n \frac{S_{r 0}}{100}\right)
$$

で与えられる。降雨強度 $I$ と厚さhの長さの単位が異な る場合にはいずれかの単位に揃える必要がある。パラメ トリック・スタディの結果より $t_{1}$ の值を読み取り，上式 から $\theta_{c p}$ の值を近似的に逆算することなどが考えられる。

一方，地下水位の持続的な上昇が開始されてからは， 雨水のすべてが地中にそのまま浸透していると仮定すれ ば, 一定の降雨強度 $I$ の降雨を想定する場合, 不飽和層 中の底部に浸透水が充填されていくことで拡大する飽和 領域の境界面（地下水面）の上昇速度 $v_{w l}$ は, 不飽和層 中の間隙を飽和させるのに必要な水の体積に基づいて, 理論的に下式で与えられる。

$$
v_{w l}=\frac{I}{n\left(1-S_{r}^{*} / 100\right)}
$$

なお，条件に応じて実際には上式とはやや異なった見 かけの上昇速度が得られることを想定し，本項では速度 の補正係数 $\alpha_{v}$ を乗じた下式を用いて一般化する。

$$
v_{w l}=\frac{\alpha_{v} I}{n\left(1-S_{r}^{*} / 100\right)}
$$

一定の降雨強度 $I$ の降雨を想定する場合, 雨水のすべ てが地中にそのまま浸透していると仮定すれば, 地下水 位が上昇し始めてから, 不飽和層すべてが飽和化して, 地表面に地下水位が達するまでの経過時間 $t_{2}$ は,

$$
t_{2}=\frac{h}{v_{w l}}=\frac{n\left(1-S_{r}^{*} / 100\right) h}{\alpha_{v} I}
$$

で与えられる。パラメトリック・スタディの結果より $t_{2}$ の値を読み取り，上式から $\alpha_{v}$ の值を近似的に逆算するこ となどが考えられる。

以上で提案した簡易予測式（補正前）のモデル概念図 が図- 5 である。降雨初期の水位未上昇の段階（ $\theta_{c p}$ が 重要）と, 水位が上昇している段階（ $\alpha_{v}$ が重要）の二つ の過程で構成されている。次節以降においては, 種々の

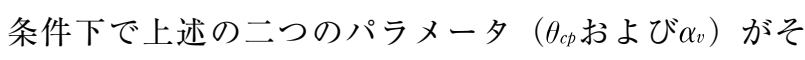
れぞれどのような值として定まるのかに着目する。

\section{4 降雨強度の異なるケース}

前節までに紹介した基本ケースに扔いて，降雨強度を 対数的に 4 通りに変化させた各ケースの結果を図-6に, 各ケースを提案モデルで近似した時に逆算される $\theta_{c p}, \alpha_{v}$ の值を表- 2 に示す。降雨強度が異なる各ケースにおい ても, 水位が上昇せずに不飽和層内の飽和度がほぼ一定 速度で上昇する時間带と, 水位がほぼ一定の速度を維持 して上昇する時間帯の二つの時間区間に単純化したモデ ル化は，一定の合理性があると考えられる。

表 -2 の $\theta_{c p}, \alpha_{v}$ の值は, 各ケースのFEM解析結果に合 うように逆算されたものであるが，逆に，これらをあら かじめ既知の定数として与えないと, 将来予測ができな い。仮にここでは $\theta_{c p}=0.07, \alpha_{v}=2.1$ (一定值) として, 各ケースのFEM解析結果としての $t_{1}$ と $t_{2}$ の值を本提案手 法でどの程度予測できるのかを確認する。表一 2 を見る と, $\theta_{c p}$ の值は降雨強度の大きさによって変化する関数

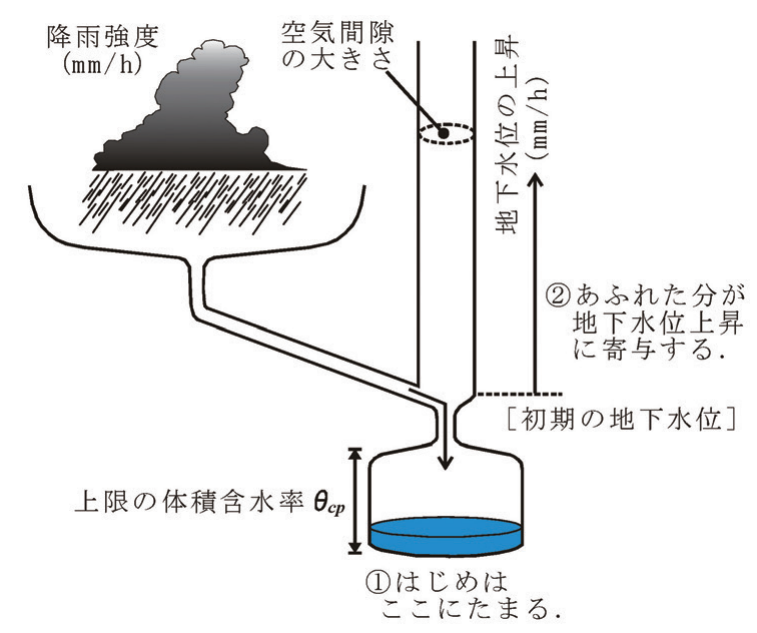

图一 5 提案手法の概念モデル.

Fig. 5 Conceptual figure of proposed model. 


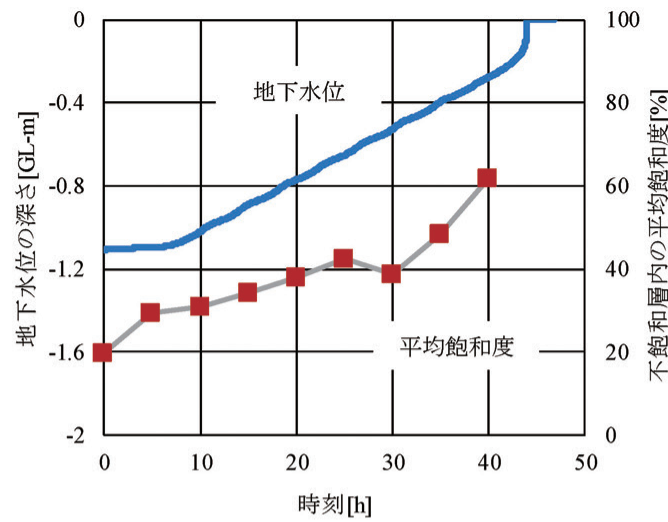

(a) $I=3.2 \mathrm{~mm} / \mathrm{h}$ の場合

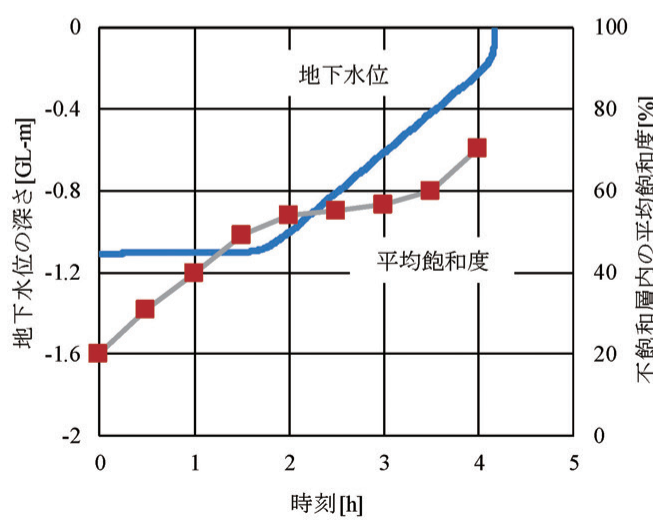

(c) $I=32 \mathrm{~mm} / \mathrm{h}$ の場合

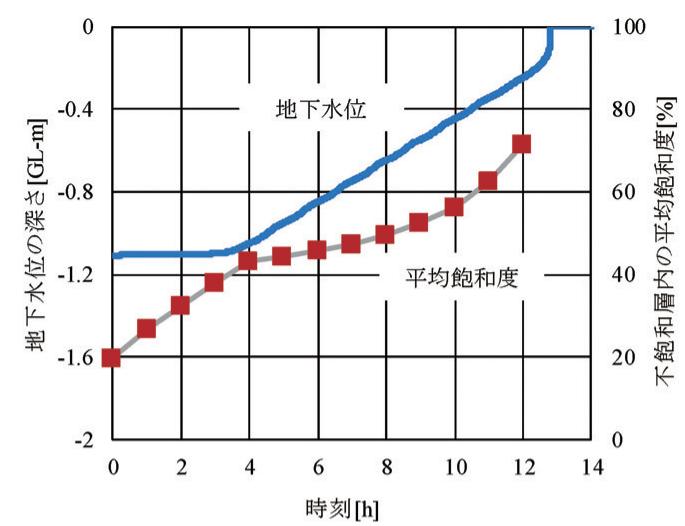

(b) $I=10 \mathrm{~mm} / \mathrm{h}$ の場合（再掲）

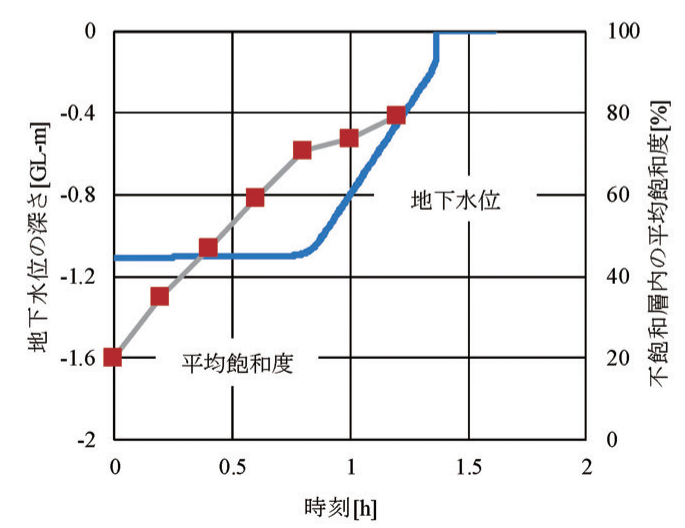

(d) $I=100 \mathrm{~mm} / \mathrm{h}$ の場合

図一 6 各降雨強度の条件下における地下水位と平均飽和度の時刻歴（基本ケース）.

Fig. 6 Time histories of ground water level and degree of saturation in cases of various rainfall intensity (Standard case).

表一 2 各降雨強度の条件下で逆算して得られた $\theta_{c p}$ おび $\alpha_{v}$ の值（基本ケース）.

Table 2 Back calculated values of $\theta_{c p}$ and $\alpha_{v}$ in cases of various rainfall intensity (Standard case).

\begin{tabular}{c|c|c|c|c|c}
\hline \multirow{2}{*}{$\begin{array}{c}\text { 降雨強度 } \\
I[\mathrm{~mm} / \mathrm{h}]\end{array}$} & \multicolumn{2}{|c|}{ FEM 解析結果から読み取った值 } & \multicolumn{2}{c}{ 提案モデルにより逆算した值 } \\
\cline { 2 - 6 } & $t_{1}[\mathrm{~h}]$ & $S_{r}^{*}[\%]$ & $t_{2 p}[\mathrm{~h}]$ & $\alpha_{v}[-]$ \\
\hline 3.2 & 6.0 & 30 & 38.5 & 0.077 & 1.89 \\
\hline 10 & 3.5 & 40 & 9.4 & 0.092 & 2.13 \\
\hline 32 & 1.7 & 51 & 2.5 & 0.11 & 2.04 \\
\hline 100 & 0.84 & 71 & 0.50 & 0.14 & 1.93 \\
\hline
\end{tabular}

のようにも考えられるが，簡単化のため，より小さな $t_{1}$ の值 (安全側) が得られる表- 2 中の最小值に近い $\theta_{c p}$ $=0.07$ を採用した。眓 -7 は $t_{1}$ と $t_{2}$ それそれに対して両 者を比較したもので, 縦軸が本提案手法による予測值, 横軸がFEM解析による結果である。すでに述べた 4 つ のケース（図中の青点）に加えて, 降雨開始時の不飽和 層内の平均飽和度が約 $13.4 \%$, 地下水位の深さが約 1.44 $\mathrm{m}$ （すなわち，これまでの 4 ケースよりも含水率の低い 条件）の 4 つのケース（図中の橙色点）をあわせて示し た。図中のマーカー形状の違いは降雨強度の違いを表す もので, $\square, \diamond, \bigcirc, \triangle$ の順にそれぞれI=3. 2, 10, 32, 100 $\mathrm{mm} / \mathrm{h}$ である FEMと提案手法の予測結果の一致度は 良好であることがわかる。大半の点が図の右上がり対角
線に近いやや下側に分布していることは，提案手法の方 がやや時刻を短めに予測することを意味し，工学的には 安全側である。

このように，材料ならびに初期の含水率や地下水位が 定められれば，それに対する任意の降雨強度の条件下で の水位上昇のモデル化を行える可能性が示唆された。な お, 不規則な降雨履歴の入力に対しての提案手法の妥当 性については後の章の中で議論する。こうして与えるべ き $\theta_{c p}, \alpha_{v}$ の值が，斜面の傾斜角度，ならびに降雨開始時 の不飽和層の厚さと平均飽和度, 透水特性等に応じてど のように変化するのか, 種々の条件を網羅したパラメト リック・スタディについて次章で述べる。 


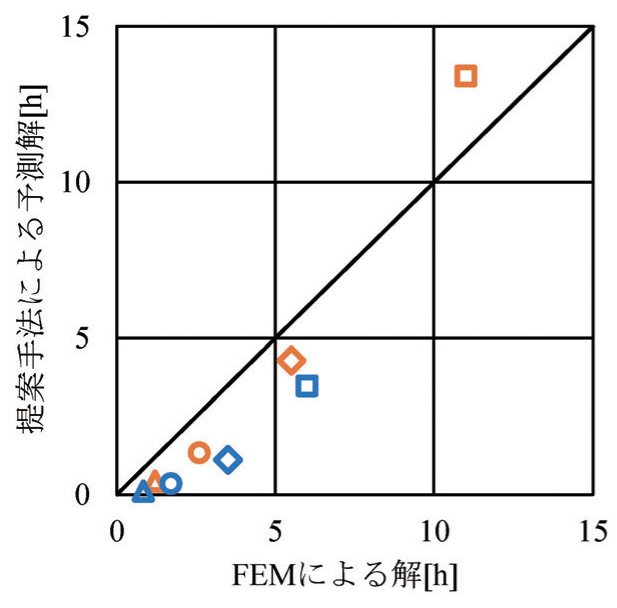

(a) $t_{1}$ の比較

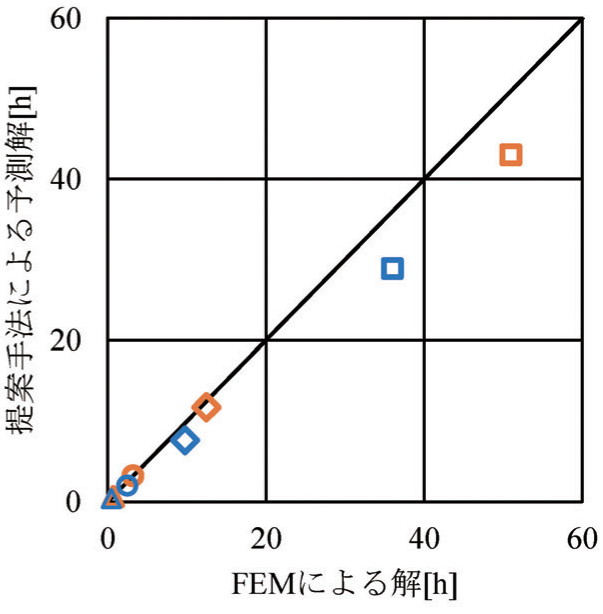

(b) $t_{2}$ の比較

図ー $7 t_{1}$ および $t_{2}$ に関するFEM解と提案手法による予測値の比較（基本ケース）.

Fig. 7 Correlation charts between results of FEM and proposed method (Standard case).

\section{4. 一般的な条件下への提案手法の拡張}

\section{1 半無限斜面を仮定した解析モデル}

斜面の表層崩壊の危険度を簡易に予測するための最も 単純なモデル化は，半無限斜面の仮定に基づいた斜面安 定解析であろう（例えば，木村ほか, 2019）。本研究にお いても半無限斜面を仮定する。半無限斜面に対して地表 面からの一様な降雨浸透を再現するには，一定勾配を有 する単位区間の有限要素モデルにおいて下流側側面の全 水頭が上流側側面の全水頭に比べて勾配の分だけ低下す るような境界条件を与えねばならないが，数理操作上は なかなか容易ではない。本研究においては，簡略化のた め，一定勾配を有する長大斜面の有限要素モデルを作成 するとともに，その左右端部は単純に非排水条件とし， 降雨が継続する間に左右端部の影響が及ばない“解析モ デルの中央付近の区間”の解析結果のみを採用した（図 - 8)。降雨時間が長くなればなるほど，また，透水係 数が大きくなればなるほど，次第に左右端部の影響が端

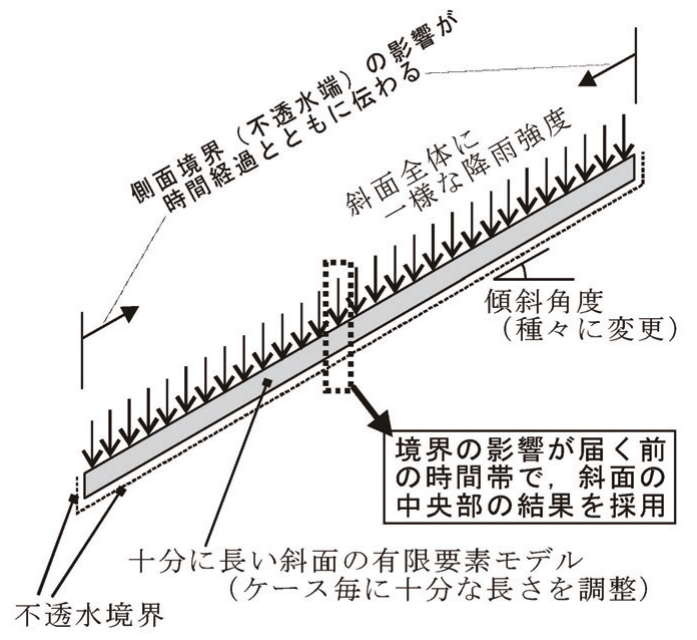

図一 8 FEM解析における半無限斜面仮定の取扱い.

Fig. 8 Boundary conditions used in 2D FEM for implementing infinite slope assumptions.
部から徐々に中央に伝播してくる。半無限斜面の仮定が 保持されるような区間が斜面の中央付近に残るために最 低限どの程度の斜面長が必要なのかを，試行錯誤に基づ く予備的検討によってあらかじめ確認している（亀 山,2017）が，紙面の都合上その詳細は省略する。

\section{2 パラメトリック・スタディ}

前章で提案した手法を多様な条件下に適用するため, 計算条件を種々に変化させながら，FEM解に適合する $\theta_{c p}, \alpha_{v}$ の值をケース毎に逆算するとともに，それらの平 均的な数值を用いてFEMによる予測結果をどの程度再 現できるかを検討した。条件を変化させた範囲について 表－3にまとめる。実施した計算ケース数は，表－1の 「中砂」あるいは「粗砂」の材料を仮定した計算ケース で，それぞれ96ケースずつ（計192ケース）とした。表 - 3 の最右列の各条件の変動刻み数の積を求めると, $2 \times$ $4 \times 2 \times 3 \times 4=192$ ケスとなることを確認されたい。 斜面の傾斜角度や透水係数の值に応じて図 -8 で述べた 有限要素モデルの必要な斜面長は異なるため，解析結果 を採用する斜面中央部の水圧分布が斜面傾斜方向に変化 せずに一様であるかどうかを点検しながら，ケース毎に 必要な斜面長を確保していることを確認した。

ところで，透水性の大きな「粗砂」を仮定したケース 中のごく一部のケース（斜面角度が $15^{\circ}$ 以上，基盤まで の地層厚さが $2 \mathrm{~m}$ 以上）において，降雨強度が小さい場 合 $(I=3.2 \mathrm{~mm} / \mathrm{h})$ には長時間の降雨の後でも地下水位 が一向に上昇しない結果となった。こうした排水性の高 い条件ケースにおいては，そもそもダミー降雨による計 算過程においても水圧の変化が極めて小さく，平衡計算 後に地下水位が現れない結果となっている。これらの ケースでは, 従来の方法で $t_{1}$ と $t_{2}$ の值を求めることはで きないため, 以降のFEMとの比較検討の際には対象か ら除外している。一方，後述のように，本提案手法では こうしたケースにおいても他ケースと同じ $\theta_{c p}, \alpha_{v}$ を採用 
表ー 3 パラメトリック・スタディで操作した各条件の範囲（計192ケース）.

Table 3 Targeted conditions in parametric studies (totally 192 cases).

\begin{tabular}{|c|c|c|c|}
\hline \multirow[t]{2}{*}{ パラメータ } & \multicolumn{2}{|c|}{ 変動範囲 } & \multirow{2}{*}{$\begin{array}{c}\text { 変動範囲内における } \\
\text { 変動刻み階数 }\end{array}$} \\
\hline & 最小值 & 最大值 & \\
\hline $\begin{array}{c}\text { 地層の浸透特性 } \\
\text { (透水係数等) }\end{array}$ & 「中砂」相当（表-1） & 「粗砂」相当（表-1） & 2 通り \\
\hline 斜面の傾斜角度 & $0^{\circ}$ & $45^{\circ}$ & 4 通り（15 刻み） \\
\hline $\begin{array}{c}\text { 降雨開始時の不飽和層 } \\
\text { の平均飽和度 } S_{r 0} \\
\end{array}$ & $\begin{array}{l}8.2 \% \text { (「中砂」の場合） } \\
2.1 \% \text { (「粗砂」の場合） } \\
\end{array}$ & $\begin{array}{l}36.0 \% \text { (「中砂」の場合) } \\
27.9 \% \text { (「粗砂」の場合) }\end{array}$ & $\begin{array}{l}2 \text { 通り（ケース毎に最 } \\
\text { 大・最小值は異なる） }\end{array}$ \\
\hline $\begin{array}{r}\text { 降雨開始時の地下水位深さ } \\
\text { (不飽和層の鉛直厚さ) } h \\
\end{array}$ & $\begin{array}{l}0.57 \mathrm{~m} \text { (「中砂」の場合) } \\
0.66 \mathrm{~m} \text { (「粗砂」の場合) }\end{array}$ & $\begin{array}{l}2.2 \mathrm{~m} \text { (「中砂」の場合 }) \\
3.0 \mathrm{~m} \text { (「粗砂」の場合 })\end{array}$ & $\begin{array}{l}3 \text { 通り（ケース毎に最 } \\
\text { 大・最小值は異なる） }\end{array}$ \\
\hline 降雨強度 $I$ & $3.2 \mathrm{~mm} / \mathrm{h}$ & $100 \mathrm{~mm} / \mathrm{h}$ & 4 通り（対数刻み） \\
\hline
\end{tabular}

して予測を行う。すると，ある長時間の降雨経過後に地 下水位が上昇する予測結果となるが，実はこれは実務上 は安全側の結果であるため，今回は特に問題にしないこ ととする。

$\mathrm{FEM}$ 解に適合するように逆算された各ケースの $\theta_{c p}, \alpha_{v}$ の值の紹介は紙面の都合上省略する。地層の浸透特性が 「中砂」の場合には $\theta_{c p}=0.07, \alpha_{v}=2.1$ を「粗砂」の場合 には $\theta_{c p}=0.04, \alpha_{v}=2.1$ をそれぞれ一定值として適用して $t_{1}$ と $t_{2}$ を推定し，これをFEMで予測した結果と比較した
相関図を図 -9 (「中砂」の場合 $)$ と図 -10 (「粗砂」の場 合）にそれぞれ示す。各散布図において，対角線への近 さの度合いを表す指標として，平均平方二乗誤差 (RMSE) を図中に記載した。いずれの材料の場合も $t_{2}$ の相関性は良好である。 $t_{1}$ について，一部の点が図の 対角線から大きく外れているものの, 全体的な傾向とし ては両者の相関傾向は悪くないと言える。

\section{3 予測精度向上のための提案手法の補正}

図 -9 , 図-10で示した $t_{1}$ の予測值に関して, 提案手法

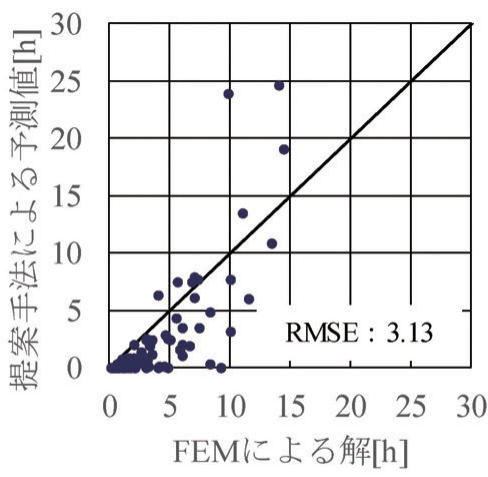

(a) $t_{1}$ の比較

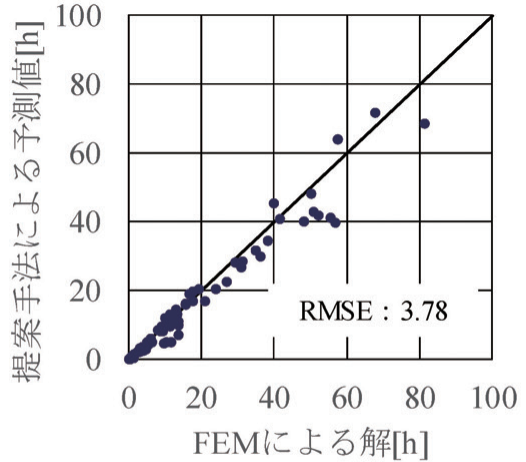

(b) $t_{2}$ の比較

図一 9 t $t_{1}$ おび $t_{2}$ に関するFEM解と提案手法による予測值の比較(「中砂」に関する全96ケース).

Fig. 9 Correlation charts between results of FEM and proposed method (96 medium sand cases).

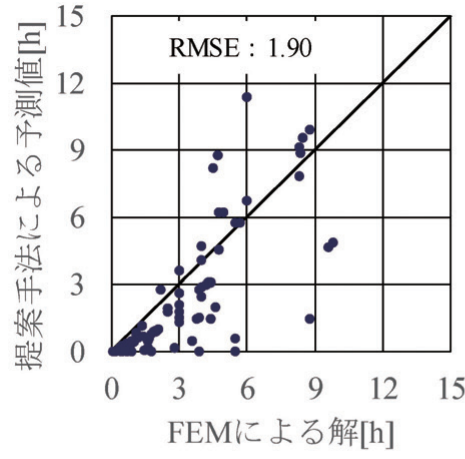

(a) $t_{1}$ の比較

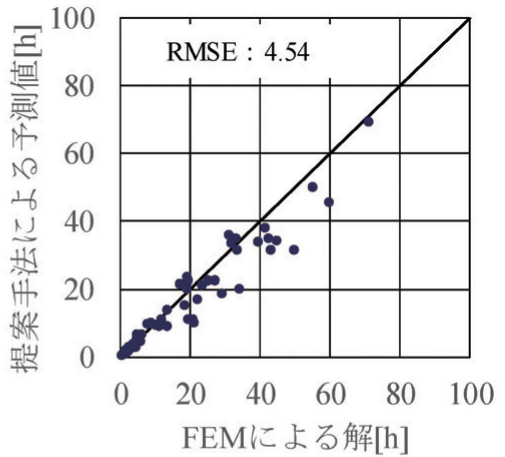

(b) $t_{2}$ の比較

図-10 $t_{1}$ および $t_{2}$ に関するFEM解と提案手法による予測值の比較(「粗砂」に関する全 96 ケース).

Fig. 10 Correlation charts between results of FEM and proposed method ( 96 coarse sand cases). 
とFEM解との相関性をさらに向上させるため，パラメ トリック・スタディの各ケースの結果を詳細に確認した。 各ケースの計算条件が $t_{1} の$ 予測結果に与える感度を分析 したところ，式（3.2）を用いて $t_{1}$ を求める際に用いるI と $S_{r 0}$ が，特に予測結果に深く関連していることがわかっ た。以上二つのパラメータの $t_{1}$ の予測值への感度をやや 抑制するように，その值に逆比例するような調整を行う と，格段に予測精度が向上することが確認された。

すなわち，

$[$ 補正後の $\tilde{I}]=[$ 補正前のI $] \div\left(\log _{10} I\right)$ $(4.1)$

（※ただし，Iの単位は $[\mathrm{mm} / \mathrm{h}])$

$\left[\right.$ 補正後の $\left.\tilde{S_{r 0}}\right]=\left[\right.$ 補正前の $\left.S_{r 0}\right] \div\left(\log _{10}\left(S_{r 0}{ }^{2}\right)\right) \cdots(4.2)$

（※ただし， $S_{r 0}$ の単位は $[\%] ）$ と置換した上，式 $(3.2)$ を用いて $t_{1}$ を求めることにす る。ただし，負值への補正を避けるため，右辺の対数の 真数が 1 以下の場合には，補正は行わない。

また，地表面の降雨水が深部へ浸透する際，地層内特 に地下水位に近い部分では，飽和度の上昇とともに次第 に流速が大きくなり，やがて水分は重力に従って整然と 鉛直下方へ単純に浸透するだけでなく，斜面傾斜と平行 な方向の移動成分の存在が無視できなくなってくる（斜 面の傾斜角度が増すにつれて，鉛直下方への浸透速度が 見かけ上やや小さくなる）と考えられる。これは，半無 限斜面において斜面平行方向の定常浸透流を考慮すると， 理論的に浸透流内の圧力水頭が，斜面方向の位置水頭の 変化分と合わせて全水頭になることから，結果的に静水 圧より小さくなることと類するものである。今回はこう した効果を考慮するための見かけ上の遅延効果の補正も 行うこととした。 $\theta_{c p}$ の值を調整する数多くの試行錯誤 計算に基づいて，傾斜角度の増加に応じて表 - 4 のよう に少しずつ増加する $\theta_{c p}$ の值を採用した。

補正前（4.2節まで）に使用していた $\theta_{c p}$ の值(「中砂」 は $\theta_{c p}=0.07$,「粗砂」は $\theta_{c p}=0.04 ）$ と表 -4 の值の変動 範囲とを比較すると，これらは一部大きく異なる。これ は, 式 (4.1)，(4.2) による補正によって, 結果的に $\theta_{c p}$ の最適值が変わったためである。式 (4.1)，（4.2）に

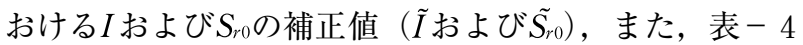
に基づく $\theta_{c p}$ の值の斜面角度による微調整，いずれの採 用值についても，その数值の妥当性に関しては必ずしも 理論的に明確な根拠はないが，試行錯誤計算の結果，こ れらの補正を組み合わせて採用することで，FEM解と の整合性が飛躍的に高まることを確認したため，こうし
た方法を採用したことに注意されたい。

一方， $t_{2}$ を求めるための式（3.5）については，式中 の各パラメータについて式 (4.1)，(4.2）のような補正 は行わず，パラメータ $\alpha_{v}$ の值については, 従前の值( 砂」の場合も「粗砂」の場合も $\alpha_{v}=2.1$ ）を採用した。

$t_{1}$ を求める際に以上の補正を加えた提案手法の予測值 とFEM解とを比較した相関図を図－11(「中砂」の場合) と図 - 12(「粗砂」の場合) にそれぞれ示す。補正前後の 対応する散布図同士のRMSEの值を比較すると自明であ るが，図－9(a)および図 -10 (a)における $t_{1}$ に比べて両 者の一致度は飛躍的に向上しており, 以上の補正の組合 せが，FEM解との整合の観点からは有効と考えられる。 以降では，この補正を加えた計算結果を標準的な計算法 として取り扱うものとする。

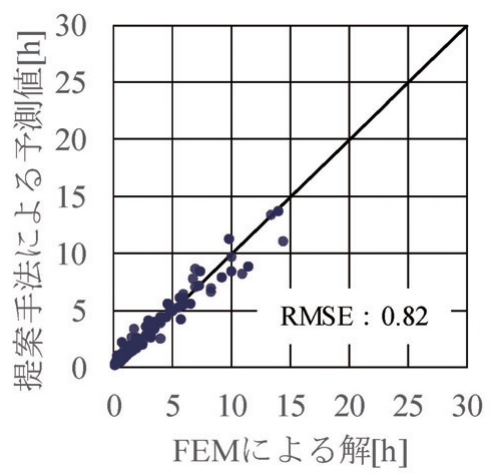

図一11ｔ１関するFEM解と提案手法（補正後） による予測值の比較(「中砂」の全96ケース).

Fig. 11 Correlation charts between results of FEM and proposed method (96 medium sand cases) after improvement of control parameters.

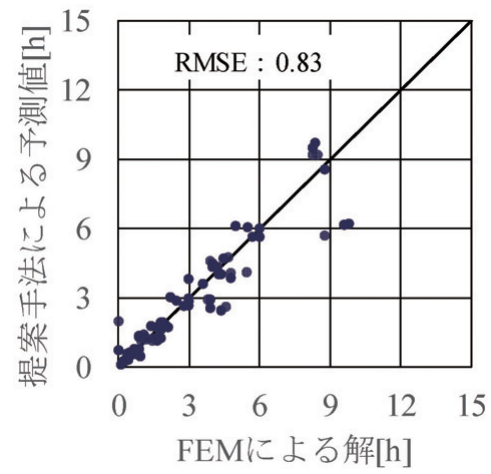

図一12 $t_{1}$ に関するFEM解と提案手法（補正後） による予測値の比較 (「粗砂」の全96ケース).

Fig. 12 Correlation charts between results of FEM and proposed method (96 coarse sand cases) after improvement of control parameters.

\section{表一 4 斜面の傾斜角度毎に異なる值を採用する補正後のパラメータ $\theta_{c p}$ の一覧.} Table 4 Improved $\theta_{c p}$ values considering slope inclination dependency.

\begin{tabular}{c|c|c|c|c}
\hline 斜面の傾斜角度 & $\mathbf{0}^{\circ}$ & $\mathbf{1 5}^{\circ}$ & $\mathbf{3 0}^{\circ}$ & $\mathbf{4 5}^{\circ}$ \\
\hline 中砂の $\theta_{c p}$ & 0.054 & 0.056 & 0.058 & 0.060 \\
\hline 粗砂の $\theta_{c p}$ & 0.036 & 0.038 & 0.040 & 0.042 \\
\hline
\end{tabular}




\section{5. 不規則降雨の場合の提案手法の有効性検証}

\section{1 任意の降雨入カに対応した計算アルゴリズム}

前章までに，降雨強度が一定の場合を対象として計算 方法を提案した。これを実際の降雨履歴の入力に対応し たモデルに拡張するため，本章では不規則降雨を入力し た場合の提案手法の拡張とその妥当性について述べる。

斜面の構成材料は表 -1 で示した「中砂」 $\left(K_{s}=1.0 \times\right.$ $\left.10^{-4} \mathrm{~m} / \mathrm{s}\right)$ もしくは「粗砂」(同 $\left.1.0 \times 10^{-3} \mathrm{~m} / \mathrm{s}\right)$ のいずれ かとし, 斜面の傾斜角度に応じて表 -4 に基づく $\theta_{c p}$ の 值を用いることとする。降雨が開始する前の地下水位以 浅の不飽和層の初期の厚さh（地表面からの鉛直深さ） および同層内の初期平均飽和度 $S_{r 0}$ はそれぞれ計算条件 としてあらかじめ与えられているものとする。

地下水位が上昇し始める瞬間，地下水位以浅の不飽和 層内の単位水平断面積の土柱（鉛直厚さ $h$ ）に蓄えられ ている水の体積 $\theta_{c p} h$ は, 降雨強度 $I$ が一定の条件下で $t_{1} に$ 対して導いた式（3.2）を拡張することで表現される。 すなわち，Iと $t_{1}$ の積の代わりに，時間とともに変化し うるIの值に経過時間 $t$ を乗じた積分值を用いて，下式 で与えられる。

$$
\theta_{c p} h=n \frac{\tilde{S_{r 0}}}{100} h+\int_{0}^{t_{1}} \tilde{I} d t
$$

繰返しになるが, 間隙率 $n$ の值は一般には飽和体積含 水率 $\theta_{s}(=0.30$; 表 -1 を参照 $)$ に等しい。なお，前章 で述べたように，式（5.1）で用いるIと $S_{r 0}$ は式 (4.1)

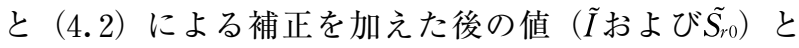
する。

式 (5.1) の右辺は, 降雨強度 $I$ の雨が時間 $\Delta t$ だけ入 力した時の土柱内の水の合計体積を算出するものである。 右辺第一項が降雨前に土柱内にすでに含まれていた水の 体積, 右辺第二項は降雨によって増加した水の体積であ る。不規則降雨の場合, 刻々と変化する降雨強度 $\tilde{I}$ の值 を差分時間間隔 $\Delta t$ 毎に与え, 右辺第二項に逐次加算し ていけばよい。降雨開始当初, 地下水位は不変であるが, 式（5.1）の右辺の合計值があらかじめ定められた $\theta_{c p} h$ の值に達した瞬間に，地下水位の上昇が開始する。

地下水位の上昇が開始した後, その上昇量については, 式（3.4）に基づいて, 時間 $\Delta t$ （降雨強度 $I ）$ の間に水 位上昇する高さ $v_{w l} \Delta t$ として下式で得られる。

$$
v_{w l} \triangle t=\frac{\alpha_{v}}{n-\theta_{c p}} I \Delta t
$$

「中砂」と「粗砂」ともに $\alpha_{v}=2.1$ である。また, 前章 で述べたように, 上式で用いるIの值については, 式 （4.1）による補正は行わないことに注意されたい。あと は, 初期の不飽和層の厚さ $h$ を地下水位の初期值として, 降雨強度 $I$ の時刻歴に従い, 式 (5.2) による前進差分 計算（差分時間間隔 $\Delta t$ ）を行えばよい。計算精度の確 保のため, 降雨強度 $I$ のデー夕間隔の粗さによっては, $\Delta t$ をよりさい時間間隔に細分割することも考えられ る。以降の計算においては，Iのデー夕間隔，差分間隔
$\Delta t$ ともに10[min] (すなわち0.1667[h]) とする。

本研究においては，地下水位が地表面に到達した時点 で差分計算は打ち切りとした。実際には，集水地形でか つ透水性が良好な透水層が斜面内にあれば，降雨中から 斜面上方よりさらに地下水が流入し, 地下水位が急上昇 する可能性もあるため，注意が必要である。以上に述べ た計算手順の概略を模式的なフロー図に取りまとめたも のが図-13である。

\section{2 各計算ケースの入力降雨と斜面条件}

図-14の 6 種類の実降雨データを用いて, 不規則降雨 の条件下における提案予測式とFEM解との整合性を確 認する。これら降雨データの観測された事象と観測点に ついて表－5にまとめた。本章においてそれぞれの実降 雨データを用いて地下水位の応答計算を行った 6 ケース の斜面条件を表一 6 に示す。地層の浸透特性(「中砂」ま たは「粗砂」), 斜面の傾斜角度，ならびに降雨開始時の 地下水位深さ（これに応じて降雨開始時の不飽和層の平 均飽和度）を種々に変えて試行した計算結果を以降に示 す。いずれも，提案する簡易予測式とFEM解との地下 水位の時刻歴を比較することとした。ここで，表－6で 取り上げた各計算条件は，いずれも提案手法の有効性を 検証するために無作為に選んだ条件の例示であり，対応 する表－5の個々の事例における斜面の水理特性等をそ れぞれ反映した条件ではない。また，表－6以外のより 多様な計算条件下においても，提案手法は以降に示す結 果と同程度の良好な結果が得られていることを付記する。

\section{3 提案手法の妥当性確認}

実施した 6 ケースの計算結果（提案手法による予測と FEM解との比較）を図－15に示す。各図中の曲線の色 は，それぞれのケースで入力した降雨データ（図－14） と対応しているので比較参照されたい。降雨が始まった 後ある一定の雨量が累積するまでは地下水位の上昇がな く，その後に地下水位の上昇が始まる，という全体的な 傾向がよく表現できており，かつ水位上昇の開始する時 刻，上昇が始まってから水位が地表面に達する時刻，い ずれも両者はよく一致している。様々な斜面条件下で異 なる降雨デー夕を入力したいずれのケースにおいても両 者の一致度は良好である。なお，ケース 2 は，先述のよ うに，降雨強度が小さい場合には地下水位が一向に上昇 しない斜面条件（粗砂，斜面角度が $15^{\circ}$ 以上，基盤まで の地層厚さが $2 \mathrm{~m}$ 以上）であるため，降雨強度が大きく なる20時間目あたりまではほとんど水位が上昇していな い。降雨強度を一定とした条件下でのパラメトリック・ スタディをもとにして構築した本提案手法が，こうした 不規則な降雨強度の時刻歴を入力した場合にも同様に有 効であることが確認された。

\section{5. まとめ}

本研究では, 斜面内の浅層地下水の水位上昇の時刻歴 を予測するための簡易な計算方法を，半無限斜面仮定の 


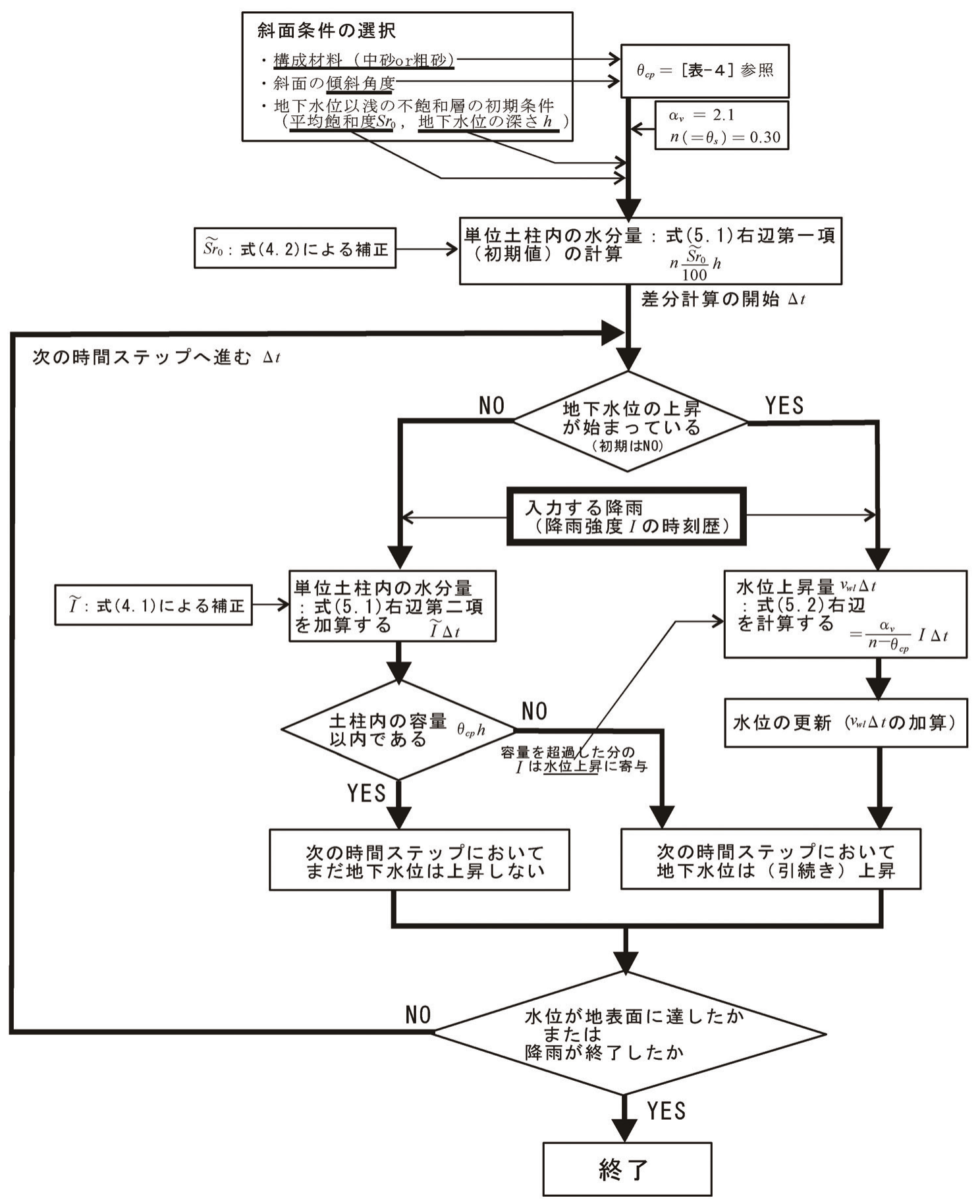

図一13提案する計算手法のフロー図.

Fig. 13 Flow chart of proposed method.

下で実施した一連の有限要素解析のパラメトリック・ス タディの結果に基づいて開発した。

広域的視点の防災シミュレーションへの応用を想定し た場合，個別の斜面の浸透特性について，あらかじめ各 斜面の詳細な地層構造や水分保持特性などが把握できて いることは少なく，大まかな地質等に基づいて透水係数 のオーダーが推定できる，といった程度の粗い条件しか 与えられていないことが考えられる。そこで，本研究の パラメトリック・スタディにおいては, 飽和透水係数が $1.0 \times 10^{-3} \mathrm{~m} / \mathrm{s}$ （粗砂）または $1.0 \times 10^{-4} \mathrm{~m} / \mathrm{s}$ （中砂）の
いずれかの典型的な浸透特性を有する材料から成る斜面 を仮定した。斜面の傾斜角度，降雨開始時の不飽和層の 平均飽和度, 降雨開始時の地下水位深さ（不飽和層の鉛 直厚さ）を仮定することで，任意の降雨データを入力し た条件下での地下水位の時刻歴を, FEMと近い精度で 再現できることを確認した。

本手法に基づいて，高度な計算環境を必要とせずに， 地下水位の時刻歴が簡易かつ短時間の演算によって予測 可能である。なお，本手法は斜面傾斜方向の水分移動の 影響を無視できる場合の浅層地下水位の時間的変化を特 


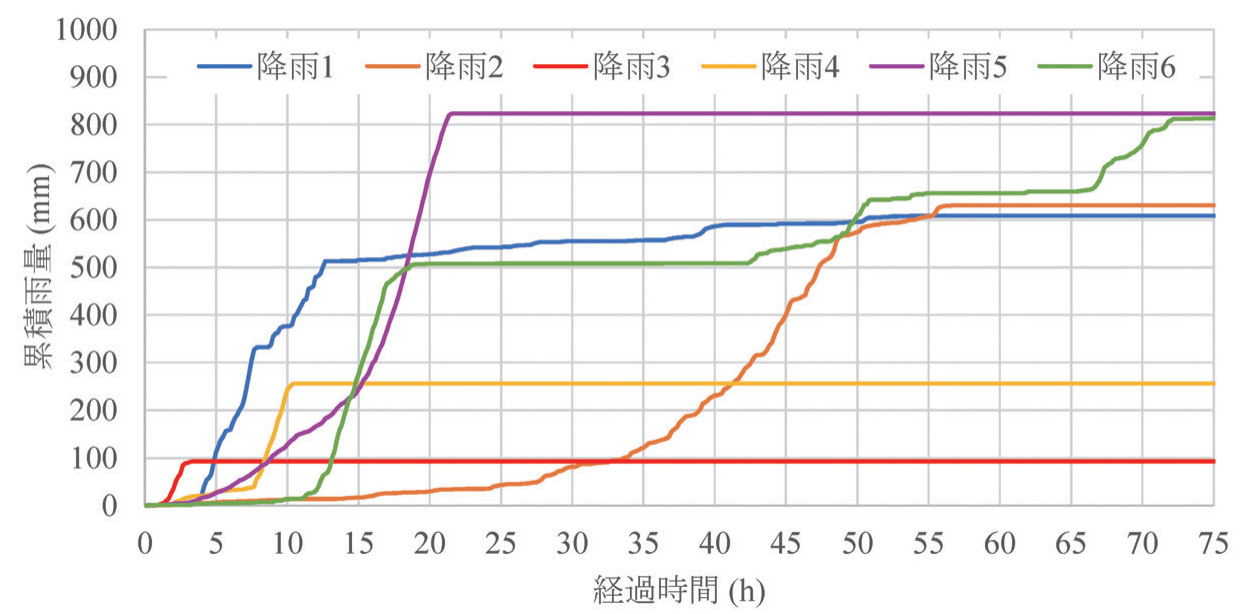

図ー14 本章の計算に用いた 6 種類の実降雨データ (累積雨量の時刻歴).

Fig. 14 Observed time histories of cumulative rainfall used in case studies.

表一 5 本章の計算に用いた 6 種類の実降雨データの観測地点.

Table 5 Observation point of each time history of cumulative rainfall used in case studies.

\begin{tabular}{c|c|c}
\hline 本章での略号 & 気象 $/$ 災害名称等 & 観測地点 \\
\hline 降雨 1 & 平成 29 年 7 月九州北部豪雨 & 朝倉（福岡県朝倉市） \\
\hline 降雨 $\mathbf{2}$ & 平成 27 年 9 月関東・東北豪雨 & 今市（栃木県日光市） \\
\hline 降雨 3 & 平成 26 年 7 月長野県南木曽町豪雨 & 南木曽（長野県木曽郡南木曽町） \\
\hline 降雨 $\mathbf{4}$ & 平成 26 年 8 月豪雨 & 広島（広島県広島市） \\
\hline 降雨 $\mathbf{5}$ & 平成 25 年台風第 26 号 & 大島（東京都大島町） \\
\hline 降雨 $\mathbf{6}$ & 平成 24 年 7 月九州北部豪雨 & 阿蘇乙姫 (熊本県阿蘇市) \\
\hline
\end{tabular}

表一 6 本章で実施した計算ケースの一覧.

Table 6 Calculated cases for various slope conditions.

\begin{tabular}{|c|c|c|c|c|c|}
\hline \multirow{2}{*}{$\begin{array}{l}\text { ケース } \\
\text { 番号 }\end{array}$} & \multirow{2}{*}{$\begin{array}{c}\text { 構成材料 } \\
\text { (表-1 参照) }\end{array}$} & \multirow{2}{*}{$\begin{array}{c}\text { 斜面の傾斜角度 } \\
{\left[{ }^{\circ}\right]}\end{array}$} & \multicolumn{2}{|c|}{ 地下水位以浅の不飽和層の初期条件 } & \multirow[t]{2}{*}{ 入力降雨 } \\
\hline & & & 平均飽和度 $S_{r 0}[\%]$ & 地下水位 $h[\mathrm{GL}-\mathrm{m}]$ & \\
\hline 1 & 中砂 & 15 & 8.2 & 1.72 & 降雨 1 \\
\hline 2 & 粗砂 & 15 & 2.1 & 2.00 & 降雨 2 \\
\hline 3 & 中砂 & 15 & 36.0 & 0.59 & 降雨 3 \\
\hline 4 & 中砂 & 30 & 17.7 & 1.45 & 降雨 4 \\
\hline 5 & 粗砂 & 30 & 2.5 & 1.00 & 降雨 5 \\
\hline 6 & 粗砂 & 30 & 4.5 & 3.00 & 降雨 6 \\
\hline
\end{tabular}

に予測するものであることから，比較的降雨時間の短い 集中豪雨型の表層崩壊の評価により適していると考えら れる。気象レーダーのデータを用いた土砂災害の危険度 評価手法などへの応用が期待される。

なお，透水係数がさらに小さい「細砂」 $\left(K_{s}=1.0 \times 10^{-5}\right.$ $\mathrm{m} / \mathrm{s}$ 程度）の場合は，本文中でも指摘したように，今回 示した解析結果とは大きく異なり, 表層から飽和帯が次 第に下降していき，それが初期地下水位に達して間もな く全層が飽和する，という経過をたどる。本研究で提案 した計算式はこうした材料は対象外としていることに注 意されたい。このような細砂様の水位変動特性を有する 斜面を対象とした計算式の提案は今後の課題である。

今後, 降雨中に斜面の傾斜方向からの地下水の流入な らびに流出が斜面全体の安定性に大きな影響を持つ一般
の斜面問題に対して本手法を応用するためには，こうし た水分移動を表現するための簡易な浸透計算アルゴリズ ムを新たに導入する必要がある。この点についても，あ わせて今後の課題とさせていただきたい。

\section{謝辞}

本研究成果の一部は, 日本地すべり学会が受託した国 土交通省平成26 28年度河川砂防技術研究課題「局地的 大雨による大規模表層崩壊発生機構の解明と危険地抽出 技術の開発」および日本学術振興会科学研究費補助金 (課 題番号17H03303)「噴火史の視点から火山砕屑物の生 成・移動過程を評価した斜面災害リスクマップの開発」 (代表：後藤 聡）の助成によるものです。ここに記し て謝意を表します。 


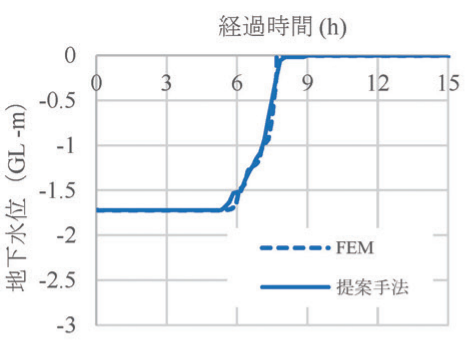

(a) ケース 1

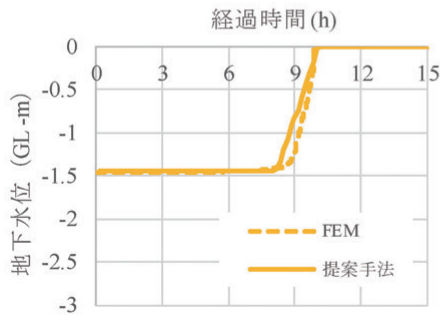

(d) ケース 4

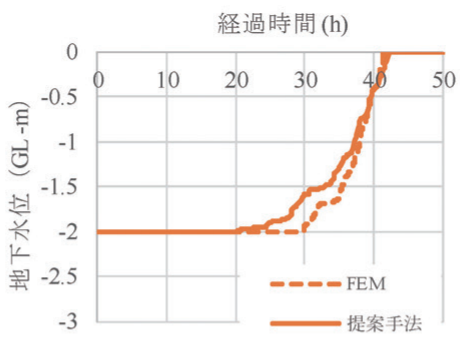

(b) ケース 2

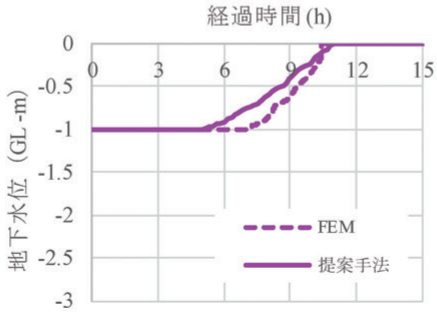

(e) ケース 5

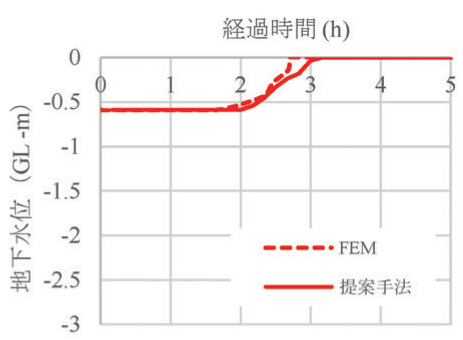

(c) ケース 3

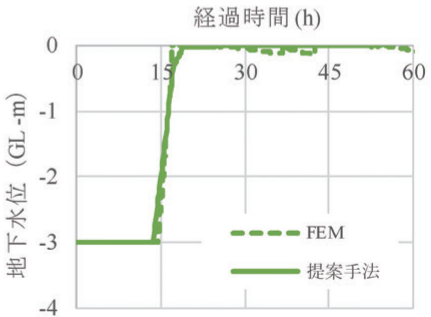

(f) ケース 6

図一15 実降雨データ入力時の地下水位の変動時刻歴 (FEM解と提案手法による解との比較).

Fig. 15 Comparisons of results between FEM and proposed method in time histories of ground water level during rainfall.

\section{引用文献}

Cai, F. and Ugai, K. (2004) : Numerical Analysis of Rainfall Effects on Slope Stability, International Journal of Geomechanics, ASCE, Vol. 4, No. 2, pp. 69-78.

Carsel, R. F. and Parrish, R. S. (1998) : Developing joint probability distributions of soil water retention characteristics, Water resources research, vol. 24, No. 5, pp. $755-769$.

Cascini, L., Cuomo, S., Pastor, M. and Sorbino, G. (2010) : Modeling of rainfall-induced shallow landslides of the flow-type, Journal of Geotechnical and Geoenvironmental Engineering, Vol. 136, No. 1, pp. $85-98$.

Cho, S. E. and Lee, S. R. (2001) : Instability of unsaturated soil slopes due to infltration, Computers and Geotechnics, Vol. 28, pp. $185-208$.

Domenico, P. A. and Schwartz, F. W. (1990): Physical and Chemical Hydrogeology, John Wiley \& Sons, New York, p. 824.

土質工学会（1967）：掘削のポイント，土質基礎工学ライブラリー 3, p. 180.

平松晋也，水山高久，石川芳治（1990）：降雨による一次元鉛直不 飽和浸透に関する実験的研究，新砂防，Vol. 43, No. 2, pp. 3-10.

亀山ひろみ（2017）：浸透流解析に基づく斜面内地下水位の上昇速 度の簡易予測モデルの提案，群馬大学大学院2016年度修士論文, 環境創生理工学教育プログラム（社会基盤・防災コース）.

Kim, J., Jeong, S., Park, S. and Sharma, J. (2004) : Influence of rainfall-induced wetting on the stability of slopes in weathered soils, Engineering Geology, Vol. 75, pp. 251-262.

木村 誇, 後藤 聡, 佐藤 剛, 若井明彦, 林信太郎, 檜垣大助 （2019）：テフラ層厚分布を考慮した斜面安定解析による崩壊危 険地の抽出一阿蘇カルデラ北東部地域における検討事例 - , 日 本地すべり学会誌, Vol. 56, Special Issue, pp. 240-249.

木下篤彦, 神野忠広, 岡本 敦, 一言正之, 小野寺勝, 桜庭雅明, 杉山 実（2013）：六甲山系におけるリアルタイムハザードマッ プシステムの構築，砂防学会誌，Vol. 66, No. 1, pp. 15-22.

三隅良平, 小口 高, 真木雅之, 岩波 越 (2004): 分布型流出乇 デルを用いた表層崩壊危険域のリアルタイム予測，自然災害科 学, Vol. 23, No. 3, pp. 415-432.

Ng, C. W. W. and Shi, Q. (1998) : A numerical investigation of the stability of unsaturated soil slopes subjected to transient seepage, Computers and Geotechnics, Vol. 22, No. 1, pp. 1-28.
Ng, C. W. W., Wang, B. and Tung, Y. K. (2001) : Threedimensional numerical investigations of groundwater responses in an unsaturated slope subjected to various rainfall patterns, Can. Geotech. J., Vol. 38, pp. 1049-1062.

西垣誠, 竹下祐二（1993）：室内及び原位置における不飽和浸透特 性の試験及び調査法に関する研究, 岡山大学工学部土木工学科, pp. $31-32$.

信岡 卓，鵜飼恵三，若井明彦，蔡 飛（2009）：降雨の非定常性 と地盤の不飽和特性を考慮した斜面安定性予測手法の検討，土 木学会論文集C, Vol. 65, No. 1, pp. 29-40.

沖村 孝，鳥居宣之，尾崎幸忠，南部光広，原口勝則（2011）：豪 雨による土砂災害を対象としたリアルタイムハザードシステム の構築, 砂防学会誌, vol. 63, No.6, pp.4-12.

Rahardjo, H., Lee, T. T., Leong, E. C. and Rezaur, R. B. (2005) : Response of a residual soil slope to rainfall, Can. Geotech. J., Vol. 42 , pp. $340-351$.

酒匂一成, 里見知昭, 菅野智之, 安川郁夫, 深川良一 (2007)：降 雨時の斜面崩壊に対する防災システムの確立に関する研究，歴 史都市防災論文集，Vol.1,pp. 167-174.

Shi, Z., Wei, F. and Chandrasekar, V. (2018) : Radar-based quantitative precipitation estimation for the identification of debris flow occurrence over earthquake-affected regions in Sichuan, China, Nat. Hazards Earth Syst. Sci., Vol. 18, pp. 765-780.

van Genuchten, M. Th. (1980) : A closed-form equation for predicting the hydraulic conductivity of unsaturated soils, Soil Soc. Am. J., Vol. 44, pp. 892-898.

若井明彦，蔡 飛，鵜飼恵三（2000）：飽和 - 不飽和浸透流解析に よる地下水位の予測と斜面の安定性評価, 日本地すべり学会誌, Vol. 36, No. 4, pp. 8-13.

若井明彦, 蔡 飛，亀山ひろみ，堀 匡佑，後藤 聡，木村 誇 （2017）: 有限要素解を援用した自然斜面内の地下水位上昇量の 簡易予測モデル（その 2 ), 第72回土木学会年次学術講演会講演 概要集, 第III部門, pp. 291-292.

Zhang, L. L., Fredlund, D. G., Zhang, L. M. and Tang, W. H. (2004) : Numerical study of soil conditions under which matric suction can be maintained, Can. Geotech. J., Vol. 41, pp. $569-$ 582.

（原稿受付2019年 1 月 7 日，原稿受理2019年 3 月18日） 